\title{
PERAN STRATEGIS FILSAFAT ISLAM DALAM PENGEMBANGAN KAJIAN PSIKOLOGI ISLAM
}

\author{
M. Zainal Abidin \\ Dosen Jurusan Akidah Filsafat Fakultas Ushuluddin IAIN Antasari \\ Banjarmasin
}

\begin{abstract}
This article tries to explore the strategic role of Islamic philosophy in developing psychological studies. There are two ways to develop psychological studies. First, studies based on Islamic tradition, and second studies based on modern psychology. The former is usually called "Islamic psychology" which is based on traditional Islamic knowledge like Islamic philosophy and Sufism, while the latter is called "psychology of Islam" which is based on certain elements of modern psychology considered in line with Islamic values. In fact, both kinds of psychological studies are important if we want to put Islam and psychology together.

Kata kunci: Turats, Modernitas, Psikologi Islam, Psikologi Islami
\end{abstract}

\section{PENDAHULUAN}

Salah satu persoalan yang mengemuka dalam diskursus pemikiran keilmuan muslim kontemporer adalah bagaimana membangun ilmu pengetahuan yang integralistik di tengah kemunduran umat Islam di bidang ilmu pengetahuan dan dominasi keilmuan moderen Barat yang sekularistik. ${ }^{1} \quad$ Upaya

${ }^{1}$ Kemunduran ilmu pengetahuan sendiri sering diparaelkan dengan inferioritas umat Islam di bidang ilmu pengetahuan. Al Attas misalnya mewujudkan ilmu pengetahuan yang integralistik ini menjadi wacana yang menarik untuk

\footnotetext{
berpandangan bahwa kemunduran Islam yang terjadi secara beruntun sejak beberapa abad belakangan ini, disebabkan oleh kerancuan ilmu (corruption of knowledge) dan lemahnya penguasaan umat terhadap ilmu pengetahuan. Karena faktor-faktor inilah jelas Al Attas, yang menjadikan umat Islam menghadapi berbagai masalah di bidang politik, ekonomi, sosial, dan budaya. Lihat Wan Mohd Nor Wan Daud, Filsafat dan Praktike Pendidikan Islam Syed M. Naquib Al Attas, (Bandung: Mizan, 2003), hal. 22.
} 
didiskusikan paling tidak karena dua alasan. Pertama, berbeda dengan realitas faktual adanya dikotomi ilmu yang terjadi di dunia muslim, ${ }^{2}$ secara normatif Islam menghendaki keilmuan yang integralistik. Islam tidak hanya berbicara mengenai persoalan menyangkut hubungan seorang hamba ('abd) dengan Tuhan semata (ㅁablum minallâh), tetapi juga banyak berbicara tentang problema kemanusiaan dan realitas kealaman secara umum. Pandangan dikotomik terhadap ilmu pengetahuan, yang memisahkan antara wahyu dengan akal atau antara pengetahuan agama dan pengetahuan umum, sejatinya tidak memiliki akar dalam ajaran Islam (Alqur'an). ${ }^{3}$

${ }^{2}$ Di Indonesia sendiri dikotomi ini menurut Mastuhu telah membentuk dua sistem pendidikan. Sistem "pendidikan agama" dan "pendidikan umum." Untuk yang pertama disebut pendidikan tradisional dan yang kedua pendidikan moderen. Selain itu, ada lagi fakultas agama dan fakultas umum; sekolah agama dan sekolah umum. Bahkan jelas Mastuhu, dikotomi itu menghasilkan kesan bahwa "pendidikan agama" berjalan tanpa dukungan iptek, dan sebaliknya, "pendidikan umum" hadir tanpa sentuhan agama. Lihat Mastuhu, Memberdayakan Sistem Pendidikan Islam, (Jakarta: Logos, 1999), hal. 3.

${ }^{3}$ Para Filosof Muslim klasik seperti Al Kindi, Al Farabi, Ibnu Sina, Ibnu Rusyd dan lain-lainnya sangat konsern dalam menampilkan pandangan
Kedua, ilmu pengetahuan moderen Barat yang dominan saat ini, karena bersifat sekularistik dan mengabaikan pada yang sakral (Tuhan/Wahyu), diyakini turut memiliki kontribusi dalam melahirkan berbagai persoalan kemanusiaan dan lingkungan, sehingga diperlukan model keilmuan yang memiliki pandangan yang berbeda, yang lebih utuh dan komprehensif dalam memandang realitas. Dalam konteks ini, ilmu pengetahuan yang integralistik dari Islam berpeluang untuk tampil menjadi pilihan dalam mengatasi berbagai persoalan kemanusiaan kontemporer. ${ }^{4}$

keilmuan yang integralistik, tidak ada dikotomi antara agama dan ilmu (filsafat), keduanya berasal dari sumber yang sama dan karenanya tidak ada yang perlu dipertentangkan karenany. Lihat misalnya Ibnu Rusyd, Falsafah Ibnu Rusyd: Fasl al-maqal wa al-Kasyfu, (Kairo: Maktabah al-Mahmudah al-Tijariah, 1968); Lihat juga ulasan dalam M.M. Syarif (ed), A History of Muslim Philosophy, (Wisbaden: Otto Harrassowitz, 1963) dan Sayyed Hossein Nasr and Oliver Leaman, History of Islamic Philosophy, Part I, (London and New York: Routledge, 1996).

${ }^{4}$ Pandangan yang cukup kritis terhadap ilmu pengetahuan moderen Barat ini dan akibat-akibat yang ditimbulkannya. Lihat misalnya, Sayyid Hossein Nasr, Knowledge and the Sacred, (New York: Crossroad, 1989); C.A. Qadir, Philosophy and Science in the Islamic World, (London: Routledge, 1988). Syed 
Di kalangan intelektual muslim kontemporer sendiri, diskusi dan perdebatan dalam upaya memajukan kembali superioritas dunia muslim dalam bidang ilmu pengetahuan sangatlah marak. Ia merupakan bagian dari arus besar pemikiran muslim setelah kekalahan bangsa Arab oleh Israel pada tahun 1967, yang kemudian melahirkan kritik internal dan berikutnya menjadi titik tolak untuk menyambut

M. Naquib Al Attas, Islam and Secularism, (Kuala Lumpur: ABIM, 1977). Nasr menyatakan bahwa sains moderen telah melakukan penindasan epistemologi dengan cara tidak mengakui cara-cara pandang lain terhadap alam, termasuk yang ada dalam agama. Kepercayaan akan realitas di luar realitas empirik hanya dianggap sebagai mitos atau takhayul belaka. Sementara itu C.A. Qadir menganggap bahwa pengabaian ilmu pengetahuan Barat terhadap yang sakral inilah yang telah mengakibatkan pengasingan dan pemisahan dalam kehidupan manusia. Manusia moderen menderita pengasingan (alienasi) dan anomie. Adapun $\mathrm{Al}$ Attas menyatakan bahwa konsep ilmu Barat lebih banyak menimbulkan masalah dan kekeliruan daripada melahirkan keharmonisan, kebaikan dan keadilan. Peradaban Barat moderen telah membuat ilmu menjadi problematis. Selain telah salah memahami makna ilmu, peradaban Barat juga telah menghilangkan maksud dan tujuan ilmu. Sekalipun, peradaban Barat moderen menghasilkan ilmu yang bermanfaat, namun peradaban tersebut juga telah menyebabkan kerusakan dalam kehidupan manusia. kebangkitan kembali dunia Islam (islamic resurgence), yakni bagaimana bersikap terhadap tradisi (turâts) dan modernitas (badâtsah). ${ }^{5}$ Dan salah satu dari produk modernitas adalah ilmu pengetahuan moderen, yang berkembang dengan sangat pesat di dunia Barat.

Dalam perkembangannya, gagasan desekularisasi ilmu oleh intelektual muslim kontemporer tersebut mulai mewujud dalam bentuknya yang lebih riil berupa lahirnya disiplin ilmu pengetahuan yang 'islami'. Di antara disiplin keilmuan yang tampaknya berhasil dikembangkan dengan baik adalah disiplin ilmu ekonomi Islam dan psikologi Islam. ${ }^{6}$ Kedua disiplin

${ }^{5}$ Ada beberapa idiomatik atau istilah yang biasa dipergunakan para pemikir Arab kontemporer, yaitu: alturâts wa al-hadâtsah (Mohammed 'Abid al- Jâbirî); al-turâts wa al-tajdîd (Hassan Hanafi); al-ashlah wa al-hadâtsab (A.H. Jidah); al-turâts wa al- mu'âshirah (A.D. Umari); dan dalam bentuk yang tidak konsisten dipergunakan juga al-qadìm wa al- jadîd (Hassan Hanafi). Seluruh istilah yang disebut ini memiliki arti arti tradisi dan modernitas dengan seluas-luas makna. Lihat A. Luthfi Assyaukanie, "Tipologi dan Wacana Pemikiran Arab Kontemporer," dalam jurnal Paramadina, Vo. I, No. 1, Juli-Desember 1998, hal. 60-62.

${ }^{6}$ Ada beberapa istilah yang dipergunakan selain psikologi Islam untuk bidang kajian kejiwaan dalam Islam, yakni psikologi islami, psikologi ilahiyah, psikologi al Qur'an, psikologi 
ilmu ini bahkan telah melembaga dalam kajian-kajian yang serius pada jenjang lembaga pendidikan formal mulai srata satu sampai strata tiga.

Secara spesifik tulisan ini bermaksud mengkaji psikologi Islam dengan perspektif dialog antara tradisi dan modernitas. Penggunaan khazanah filsafat Islam sebagai basis pengembangan kajian psikologi di dunia Islam merupakan bagian dari arus penguatan kajian yang berpijak dari tradisi yang ternyata cenderung terpinggirkan dalam khazanah kajian psikologi. Secara lebih sistematis pembahasan akan dimulai dari uraian mengenai dua model pendekatan dalam psikologi Islam, baru selanjutnya dikupas peran strategis filsafat Islam dalam pengembangan kajian psikologi.

\section{PEMBAHASAN}

1. Dua Model Pendekatan dalam Kajian Psikologi Islam

Sebagaimana diuraikan sebelumnya, dinamika keilmuan di dunia muslim kontemporer, termasuk dalam hal ini disiplin psikologi tidak bisa dilepaskan dari pergulatan antara warisan

qur'ani, psikologi motivatif, psikologi profetik, nafsiologi dan psikologi sufi. Lihat Fuad Nashori, Agenda Psikologi Islami, Yogyakarta: Pustaka Pelajar, 2002), hal. 1 (turats) dan modernitas (hadatsah). Psikologi Islam sendiri dalam wacana publik internasional, mulai bergaung sejak tahun 1978. Pada tahun itu, di Universitas Riyadh, Arab Saudi berlangsung simposium internasional tentang psikologi dan Islam (International symposium on Psychologi and Islam). Setahun sesudahnya, 1979, di Inggris terbit sebuah buku kecil yang sangat monumental di dunia muslim, yaitu the Dilemma of Muslim Psychologist yang ditulis Malik B. Badri.

Dalam konteks keilmuan, turats diasosiasikan pada khazanah keilmuan yang sangat kaya dan melimpah sebagai peninggalan (warisan) para intelektual muslim masa lampau, yang sebagian besarnya masih tersembunyi dalam rak-rak perpustakanperpustakaan dunia, dan baru belakangan mulai dikaji secara lebih intensif. Sedangkan modernitas dalam hal ini dikaitkan dengan pencapaianpencapaian keilmuan oleh peradaban Barat, yang saat ini begitu mendominasi wacana keilmuan dunia.

Terkait dengan disiplin ilmu psikologi Islam, khususnya yang berkembang di Indonesia,

${ }^{7}$ Informasi tentang simposium dan tulisan Malik B, Badri ini bisa dilihat pada Fuad Nashori, Agenda Psikologi.... hal. 23 
dialektika warisan dan modernitas telah melahirkan dua model pendekatan dalam pengkajiannya. Pertama, pendekatan yang berorientasi kepada kajian turats, yakni tradisi keilmuan dalam Islam yang membahas tentang persoalan kejiwaan, untuk pengembangan keilmuan psikologi Islam, yang lazim dikenal dengan istilah psikologi Islam. Istilah psikologi Islam digunakan dengan alasan karena mengambil sumber langsung dari khasanah klasik Islam untuk kemudian dikontekstualisasikan dengan pandangan psikologi modern.

Kedua, pendekatan yang berorientasi pada modernitas (badâtsab), yakni kajian terhadap tradisi psikologi Barat modern, yang disesuaikan dengan nilai ajaran Islam. Pendekatan yang kedua ini dinamakan dengan psikologi Islami. Penggiat pandangan yang kedua ini umumnya dilakukan oleh alumnus psikologi umum (Barat), yang tidak puas dengan bahasan psikologi yang dianggap terlalu sekularistik dan menafikan kondisi kejiwaan hakiki manusia. Karena itu, mereka melirik nilainilai Islam untuk mengatasi kekurangan psikologi modern. ${ }^{8}$

${ }^{8}$ Pada sekitar 1975-an muncul kesadaran di kalangan psikolog muslim
Psikologi Islami tampaknya merupakan bagian dari gerakan Islamisasi ilmu pengetahuan yang berhasil dengan bagus di samping disiplin ekonomi Islam. Gagasan utama gerakan ini, yaitu menyelaraskan keilmuan Barat yang dipandang sekuler dengan ajaran Islam. Gagasan ini dari segi alur berangkat dari luar (Barat) ke dalam (Islam).

Berbeda dengan psikologi islami, semangat yang mendasari psikologi Islam adalah orientasi dari dalam (Islam) ke luar (dunia). Psikologi dengan semangat yang mengkaji warisan ini termasuk marginal dan kurang mendapat perhatian yang bagus dalam kajian psikologi kontemporer di dunia Islam. Muhammad Utsman Najati menyatakan bahwa para psikolog

atas paradigma yang dikembangkan di Barat. Pertama, menafikan dimensi Tuhan dalam kajian psikologi; kedua, epistemologi yang digunakan terfokus pada empiris positivistik dan empirisisme humanistik; ketiga, tidak mengungkap ruh sebagai struktur utama kepribadian manusia; keempat, berpusat pada anthropo-sentris. Tawaran dari kelompok ini, yaitu solusi atas psikologi Barat dengan mengajukan, pertama theisme atau desekularisasi; kedua, anthroporeligius; ketiga, dimensi ruh sebagai struktur psikis (kepribadian) utama manusia. Lihat Baharuddin, Aktualisasi Psikologi Islami, (Yogyakarta: Pustaka Pelajar, 2005), hal. 36 
cenderung abai terhadap kontribusi Islam dalam bidang psikologi, bahkan termasuk para penggiat psikolog yang beragama Islam. Sejarah psikologi juga cenderung tidak memberikan perhatian yang selayaknya pada pencapaian intelektual muslim dalam bidang ini. Umumnya, jelas Najati, kajian psikologi bermula dari para pemikir Yunani, khususnya Plato dan Aristoteles. Selanjutnya, pembahasan diteruskan pada pemikiran kejiwaan para pemikir Eropa abad pertengahan dan masa renaisans Eropa modern. ' Perhatian dan penghargaan yang bagus malah diberikan oleh para pengkaji filsafat Islam, yang banyak memberikan informasi berharga akan kedalaman kajian psikologi oleh para intelektual muslim masa lampau, khususnya oleh para filosof muslim. ${ }^{10}$

Kiranya ada nilai lebih tersendiri dengan mengkaji psikologi dengan model psikologi Islam yang mengangkat kembali khazanah keilmuan klasik, karena orientasinya yang dari dalam ke luar, maka diharapkan akan memberikan kontribusi berharga bagi kajian psikologi secara

\footnotetext{
${ }^{9}$ Muhammad Ustman Najati, Jiwa dalam Pandangan Filosof Muslim, Penerjemah Gazi Saloom, (Bandung: Pustaka Hidayah, 2002), hal. 15 ${ }^{10} \mathrm{Ibid}$
}

umum. Dan keberhasilan upaya ini mau tidak mau di antaranya melalui pintu filsafat Islam, yang notebene sudah menyediakan lahan yang subur dalam upaya melahirkan disiplin ilmu psikologi yang khas Islam. Filsafat Islam karenanya memiliki nilai yang sangat strategis untuk mencapai hal tersebut.

\section{Peran Strategis Filsafat Islam dalam Kajian Psikologi \\ Filsafat}

Islam

sebagaimana dipahami oleh para filosof muslim klasik, dimaknai sebagai pengetahuan tentang hakekat segala sesuatu. Hakekat segala sesuatu di sini termasuk tentunya juga jiwa. Senada dengan hal ini, psikologi juga pada awalnya dimaknai sebagai kajian tentang jiwa. ${ }^{11}$ Psikolog di sini

\footnotetext{
${ }^{11} \mathrm{Ada}$ banyak pengertian psikologi yang mengemuka sejak pertengahan abad ke-19 yang disebut sebagai abad kelahiran psikologi kontemporer di dunia Barat. Masingmasing pengertian memiliki keunikan, sesuai dengan kecenderungan, asumsi dan aliran yang dianut oleh penciptanya. Namun, apabila disederhanakan ada tiga pemahaman terhadap psikologi yang mengemuka. Pertama, psikologi yang dimaknai sebagai kajian tentang jiwa (an nafs). Kajian yang dilakukan oleh para filosof sangat terkait dengan makna ini. Kedua, Psikologi adalah ilmu pengetahuan tentang kehidupan mental, seperti pikiran, perhatian, persepsi, intelegensi,
} 
berperan untuk merumuskan hakekat jiwa yang proses penggaliannya didasarkan atas pendekatan spekulatif. Psikologi dalam pengertian ini memiliki kelebihan tersendiri, karena dapat mencerminkan hakekat psikologi yang sesungguhnya, sebab ia dapat mengungkap hakekat jiwa yang menjadi objek utama kajian psikologi. Maka, itu sejarah awal psikologi tidak dapat dipisahkan dari filsafat, termasuk juga di sini filsafat Islam. ${ }^{12}$

kemauan, dan ingatan. Definisi ini dipelopori oleh Wilhelm Wundt. Ketiga, Psikologi adalah ilmu pengetahuan tentang perilaku organisme, seperti perilaku kucing terhadap tikus, perilaku manusia terhadap sesamanya, dan sebagainya. Definisi yang terakhir ini dipelopori oleh John Watson.

${ }^{12}$ Sebelum psikologi berdiri utuh sebagai ilmu pengetahuan pada tahun 1879, psikologi dipelajari dalam cabang filsafat dan ilmu faal. Filsafat sudah mempelajari gejala-gejala kejiwaan sejak 500 atau 600 tahun sebelum masehi, yaitu melalui filsuf-filsuf Yunani Konu seperto Socrates (469-399 SM), Plato (427-347 SM), dan Aristoteles (384-322 SM). Sedangkan para ahli ilmu faal, terutama para dokter mulai tertarik pada masalah-masalah kejiwaan ini bersamaan dengan perkembangan ilmu pengetahuan yang pesat di eropa, berpendapat bahwa jiwa erat sekali hubungannya dengan susunan syaraf dan refleks-refleks. Di antara tokohtokohnya Sir Charles Bell (1774-1842) dan Francis Magensie. Lihat Abdurrahman Saleh dan Muhbib Abdul
Mengkaji psikologi Islam dalam perspektif turats Islam, menuntut para pengkajinya untuk melihat kembali lembaranlembaran kajian psikologi Islam tatkala ia masih bersama "induk"nya, yakni filsafat Islam. Kiranya ada beberapa peran strategis filsafat Islam dalam pengembangan kajian psikologi Islam yang dapat dikemukakan, yakni sebagai berikut:

Pertama, menjaga kesinambungan kajian psikologi dalam Islam. Sebagaimana telah dijelaskan bahwa melalui disiplin filsafat Islam kita dapat mengetahui dan memahami pencapaian yang luar biasa oleh generasi muslim masa lampau dalam bidang ini. Filsafat Islam karenanya menjadi pintu masuk bagi yang mereka hendak memahami wacana dan perdebatan tentang kejiwaan dalam Islam dan memanfaatkan kekayaan khazanah kajian tersebut dalam upaya pengembangan psikologi Islam dewasa ini.

Beberapa pencapaian dan temuan yang dilakukan para filosof muslim telah menemukan padanannya pada pemikiran psikologi modern. Di antaranya seperti diungkapkan Muhammad

Wahab, Psikologi Suatu Pengantar Dalam Perspektif Islam, (Jakarta: Prenada Media, 2004), hal. 4 
Utsman Najati, bahwa dengan ketajaman pikiran dan ketelitian pengamatannya, Ibnu Sina dapat mencapai pengetahuan tentang hukum proses conditioning yang baru belakangan dipopulerkan kembali oleh Ivan Pavlov, seorang psikolog berkebangsaan Persia. Ibnu Sina juga telah memberikan interpretasi ilmiah tentang lupa dengan sangat cerdas, yakni dengan mengembalikannya pada berbagai intervensi berbagai informasi, yang kiranya belum pernah dicapai para psikolog modern, kecuali pada perempat pertama abad ke-20. Selain itu, metode penyembuhan orang yang sakit kasmaran oleh Ibnu Sina dianggap sebagai dasar bagi penemuan alat modern yang dikenal dengan sebutan alat respon kulit galvanisasi atau sering disebut sebagai alat pendeteksi kebohongan (lie detector). ${ }^{13}$

Selain Ibnu Sina, gagasan al-Kindi tentang prinsip bertahap dalam mempelajari kebiasaan yang sulit juga dipandang telah mendahului para psikolog modern tentang prinsip belajar. Prinsip ini telah digunakan oleh psikiater behavioristik modern dalam penyembuhan diri dari

\footnotetext{
${ }^{13}$ Lihat Muhammad Utsman Najati, Jiwa dalam Pandangan....hal, 17
}

kebiasaan yang buruk dan dalam menyembuhkan keresahan. ${ }^{14}$

Demikian pula ilmuwan muslim terdahulu lainnya semisal al-Kindi, Abu Bakar ar-Razi, Ibnu Miskawaih, Ibnu Hazm, alGhazali, Fakhruddin ar-Razi, dan lainnya telah mengungguli para psikolog modern dari kalangan pengikut aliran kognitif tentang konsentrasi terhadap penyembuhan jiwa dengan cara mengubah pikiran dan keyakinan individu yang negatif atau yang salah. Alasannya, pikiran dan keyakinan individu merupakan faktor yang mempengaruhi perilaku. Karena itu, ilmuwan muslim itu pada faktanya merupakan perintis terapi kognitif modern. ${ }^{15}$

Kedua, dengan menggunakan turats filsafat Islam sebagai pintu masuk, akan dimungkinkan munculnya disiplin psikologi yang benar-benar utuh dan memiliki identitas yang jelas. Hal ini karena ia tidak lagi sematamata sekadar islamisasi psikologi Barat, tetapi berpijak dari warisan khazanah keilmuan ilmuwan muslim sendiri, oleh karena itu bukan tidak mustahil akan benarbenar lahir mazhab psikologi yang khas, yang pada gilirannya dapat memberikan kontribusi pada berbagai persoalan kemanusiaan

${ }^{14}$ Ibid, hal. 35

${ }^{15}$ Ibid, hal. 17 
manusia modern, khususnya yang terkait pada masalah kejiawaan.

Pandangan Islam tentang manusia yang dianggap lebih komprehensif, kiranya dapat menjadi modal dasar ke arah ini. Baharuddin dalam kajian disertasinya mengenai elemen psikologi dalam Alqur'an menyimpulkan bahwa ada tiga aspek utama manusia menurut Islam, yakni aspek jismiah, aspek nafsiah, dan aspek rubaniah. Aspek jismiah meliputi keseluruhan organ fisik-biologis, sistem sel, kelenjer, dan sistem syaraf. Aspek nafsiah mencakup keseluruhan kualitas insaniah yang khas milik manusia, yaitu pikiran, perasaan, dan kemauan yang berasal dari dimensi al aql, al qalb, dan an nafsu. Aspek ruhaniah adalah keseluruhan potensi luhur psikis manusia yang memancar dari dua dimensi, yaitu al rub dan al fitrah. Aspek yang terakhir ini merupakan khas psikologi Islami. ${ }^{16}$

Dikaitkan dengan fokus kajian psikologi secara umum, maka diketahui bahwa Psikologi fisiologi (psikologi faal) berada pada aspek jismiah. Psikologi ini mempelajari aspek fisik diri manusia terutama pada fungsi-

16Baharuddin, Paradigma
Psikologi Islami: Studi Tentang Elemen
Psikologi dari Al Qur'an, (Yogyakarta:
Pustaka Pelajar, 2004), hal. xii-xiii

fungsi syaraf dan sistem kelenjer manusia. Psikoanalisa dan behaviorisme pada pada aspek jismiah dan aspek nafsiah terutama pada dimensi al nafsu. Keduanya memusatkan perhatian pada pengalaman, yang pertama pada masa lalu sedangkan yang kedua pada masa kini dan di sini. Psikologi humanistik berada pada aspek nafsiah terutama dimensi an nafsu, al aql, dan al qalb. Psikologi ini memusatkan perhatian pada kualitas kemanusiaan berupa pikiran, perasaan, dan kemauan. Psikologi transpersonal sebenarnya berada pada aspek ruhaniah tetapi belum mengakomodasi dimensi al rub dan al fitrah. Psikologi ini memusatkan pada kemampuan batin manusia yang terdalam yang bersifat melampaui diri pribadi manusia biasa. ${ }^{17}$

Pandangan Islam tentang potensi manusia yang komprehensif tersebut mendapat perhatian yang khusus dalam kajian filsafat Islam. Persoalan kejiwaan dalam kajian Filsafat Islam dibahas secara mendalam oleh para filosof muslim mulai aspek hulu hingga hilir, yakni mulai dari argumentasi atau bukti akan hakekat dan keberadan jiwa yang tentunya sangat teoritisfilosofis, potensi-potensi jiwa 
yang dapat dikembangkan hatta metode-metode praktis yang dapat digunakan dalam terapi langsung persoalan-persoalan yang menyangkut kejiwaan. Pandangan teoritis yang mendahului aspek praktis akan memungkinkan kesimpulan yang lebih utuh dan mendasar dalam mengambil alternatif-alternatif pemecahan.

Sebagai ilustrasi tentang bagaimana pemikiran teoritis mengenai keberadaan jiwa yang dikemukakan oleh ilmuwan muslim diungkapkan dengan cukup menarik oleh Ibrahim Madkour. Menurutnya, tidak ada karya Arab yang berpengaruh hebat dalam pemikiran latin sehebat Kitab An Nafs nya Ibnu Sina. Buku ini pasca penerjemahannya ke bahasa Latin telah menyulut sejumlah masalah di sekitar wujud, hakekat dan keabadian jiwa. Ibnu Sina, jelas Madkour, telah memberikan kontribusi besar yang sangat orisinil mengenai di antara bukti adanya jiwa, yakni uraiannya tentang orang terbang di angkasa. Intinya, jika kita membayangkan seseorang yang sehat jasmani dan intelek kemudian wajahnya ditutup hingga tidak melihat apaapa dan dibiarkan terbang di angkasa, di mana ia tidak merasakan gesekan apa-apa, maka dalam kondisi yang demikian ini ia tidak ragu bahwa ia ada. Indera maupun fisiknya tidak berperan apa-apa dalam menetapkan keberadaannya, tetapi ia dituntun oleh aspek lain yang non fisik, yakni jiwa. ${ }^{18}$

Adapun ilustrasi tentang
metode-metode dipergunakan oleh para filosof muslim sebagai terapi praktis dalam berbagai persoalan di bidang kejiwaan kiranya juga merupakan kekayaan yang sangat melimpah untuk dikaji ulang. Sebagai contoh, misalnya metode $\mathrm{Al}$ Kindi tentang terapi membebaskan diri dari kesedihan. Menurut $\mathrm{Al}$ Kindi, cara untuk membebaskan diri dari kesedihan yakni dengan memikirkan kesedihan dan membaginya menjadi dua macam. Pertama, kesedihan yang terjadi karena perbuatan yang kita lakukan; dan kedua, kesedihan yang terjadi karena perbuatan orang lain. Kesedihan yang terjadi akibat perbuatan kita sendiri, kita dapat menyembuhkannya dengan menjauhkan perbuatan tersebut. Sedangkan kesedihan yang terjadi akibat perbuatan orang lain, maka kita tidak boleh bersedih sebelum perbuatan itu terjadi. Jika perbuatan itu terjadi dan

${ }^{18}$ Ibrahim Madkour, Aliran dan Teori Filsafat Islam, Penerjemah Yudian Wahyudi, (Jakarta: Bumi Aksara, 1995), hal. 284-285 
membuat kita bersedih, maka kewajiban kita adalah berusaha untuk mempersingkat tempo kesedihan. ${ }^{19}$

Ketiga, dengan melibatkan filsafat Islam dalam kajian psikologi, akan dimungkinkan akselerasi dalam pengembangan psikologi Islam, hal ini karena sebagaimana disebutkan sebelumnya telah banyak pencapaian yang diperoleh para filosof muslim masa lampau, yang kiranya tetap relevan sampai saat ini.

Berbagai temuan-temuan para ilmuwan muslim terdahulu di bidang psikologi, kiranya dapat meningkatkan harga diri para penggiat psikologi Islam sehingga tidak perlu merasa minder atau inferior berhadapan dengan pencapaian psikologi modern. Bahkan, mereka dapat mendialogkan temuan tersebut dengan perkembangan psikologi dewasa ini. Dengan demikian psikologi Islam sebagai sebuah disiplin ilmu tidak berangkat dari titik nol, tetapi dapat melakukan akselerasi dalam kajiannya, sehingga pada gilirannya dapat mecapai apa yang dicita-citakan oleh para penggiat disiplin ilmu

\footnotetext{
${ }^{19}$ Sebagaimana dikutip Muhammad Utsman Najati dari karya Al Kindi, Al Hilah fi DafI al Ahzan. Lihat Muhammad Ustman Najati, Jiwa dalam Pandangan...., hal. 36
}

ini, yakni menjadikan psikologi Islam sebagai mazhab kelima sesudah mazhab psikoanalisa, behaviorisme, psikologi humanistik, dan transpersonal. ${ }^{20}$ Keempat, dengan melibatkan filsafat Islam dalam kajiannya, corak psikologi Islam juga dimungkinkan akan memiliki citra rasa rasional yang kental. Psikologi modern dalam perkembangannya memang sangat bernuasan empirik, karena itu psikologi Islam yang dapat mengawinkan aspek empiris dari psikologi modern dengan aspek rasionalitas dalam kajian filsafat Islam, kiranya akan membuat psikologi Islam menjadi disiplin yang memandang jiwa secara lebih komprehensif.

Selain itu, kupasan aspek psikologi dalam filsafat Islam juga pada gilirannya akan menjadikan kajian filsafat tidak lagi dipandang sebagai sesuatu yang "tidak jelas", melangit, namun benar-benar akan dirasakan manfaatnya langsung dalam upaya mengatasi berbagai penyakit aneh manusia

\footnotetext{
${ }^{20}$ Tentang visi untuk menjadikan psikologi Islam (i) sebagai mazhab kelima telah ditegaskan oleh para penggiatnya seperti Fuad Nashori, Hanna Djumhana Bastaman serta Tim Perumus Dialog Nasional Psikologi Islami di fakultas Psikologi Universitas Darul Ulum Jombang. Lihat kembali Fuad Nashori, Agenda Psikologi, hal. 23
} 
modern, yang membutuhkan penanganan yang menyeluruh

\section{PENUTUP}

Penggunaan filsafat Islam sebagai satu upaya untuk pengembangan psikologi Islam kiranya dapat menjadi satu pilihan dalam membangun kajian psikologi di dunia lebih komprehensif. Penggunaan turats Islam ini tentu juga harus tetap mengambil manfaat dari temuantemuan yang sudah sangat melimpah dalam kajian psikologi modern. Dialog yang intens antara turats Islam dengan kajian psikologi modern akan sangat membantu pada penemuan jati diri psikologi Islam.

Sebagai sebuah jurusan baru, kiranya kajian psikologi Islam di Fakultas Ushuluddin harus mengambil fokus garapan. Apabila eksponen psikologi Islami di Indonesia yang berasal dari tradisi psikologi umum telah cukup mengambil peran dalam upaya islamisasi psikologi Barat (luar ke dalam), maka harus ada kelompok ang yang juga intens mengkaji turats Islam untuk kemudian kalau perlu diekspor ke Barat (dalam ke luar), sehingga pada gilirannya keberadaan Islam akan benar-benar di rasakan manfaatnya, yakni Islam menjadi rabmatan lil'âlamin. Wallabu 'alam bi al shawab.

\section{DAFTAR PUSTAKA}

al-Attas, Syed M. Naquib, Islam and Secularism, (Kuala Lumpur: ABIM, 1977).

Assyaukanie, A. Luthfi, "Tipologi dan Wacana Pemikiran Arab Kontemporer," dalam jurnal Paramadina, Vo. I, No. 1, Juli-Desember 1998.

Baharuddin, Aktualisasi Psikologi Islami,

(Yogyakarta: Pustaka Pelajar, 2005).

Baharuddin, Paradigma Psikologi Islami: Studi Tentang Elemen Psikologi dari Al Qur'an, (Yogyakarta: Pustaka Pelajar, 2004).

Daud, Wan Mohd Nor Wan, Filsafat dan Praktik Pendidikan Islam Syed M. Naquib Al Attas, (Bandung: Mizan, 2003).

Madkour, Ibrahim, Aliran dan Teori Filsafat Islam, Penerjemah Yudian Wahyudi, (Jakarta: Bumi Aksara, 1995).

Mastuhu, Memberdayakan Sistem Pendidikan Islam, (Jakarta: Logos, 1999).

Najati, Muhammad Ustman, Jiwa dalam Pandangan 
Filosof Muslim,

Penerjemah Gazi

Saloom, (Bandung:

Pustaka Hidayah, 2002).

Nashori, Fuad, Agenda

Psikologi Islami,

(Yogyakarta: Pustaka

Pelajar, 2002).

Nasr, Sayyed Hossein and

Oliver Leaman, History of Islamic Philosophy, Part I, (London and New York: Routledge, 1996).

Nasr, Sayyid Hossein, Knowledge and the Sacred, (New York: Crossroad, 1989).

Qadir, C.A., Philosophy and Science in the Islamic World, (London: Routledge, 1988).

Rusyd, Ibnu, Falsafah Ibnu Rusyd: Fasl al-maqal wa al-Kasyfu, (Kairo: Maktabah alMahmudah al-Tijariah, 1968).

Saleh, Abdurrahman, dan Muhbib Abdul Wahab, Psikologi Suatu Pengantar Dalam Perspektif Islam, (Jakarta: Prenada Media, 2004).

Syarif, M.M. (ed), A History of Muslim Philosophy, (Wisbaden: Otto Harrassowitz, 1963). 